\title{
Comparison of $70 \%$ alcohol and $2 \%$ glutaraldehyde effectiveness to the amount of bacterial colonies on the dental chair unit In Department of Oral and Maxillofacial Surgery Faculty of Dentistry University of Sumatera Utara
}

\author{
Hendry Rusdy, ${ }^{*}$ Darmayanti Siregar, Ahyar Riza, Indra B. Siregar, Novita M. Sari
}

\section{Abstract}

Objective: Disinfection is an act to kill and eliminate all forms of microorganisms including spores with physical or chemical procedures. One of the goals of disinfection in the health sector is to prevent cross infection through microorganisms that are found in blood, saliva and dental plaque that can contaminate the work surface.

Material and Methods: This is an experimental research with pretest-posttest design. This study was conducted on 10 dental chair unit and the number of bacterial colonies is observed before and after disinfection using $70 \%$ alcohol and $2 \%$ glutaraldehyde.

Results: The results showed that the number of bacterial colonies experienced a statistically significant decrease after disinfection with $70 \%$ alcohol with mean value of $318.20 \pm 217.52$ before and $11.20 \pm 17.29$ after disinfection, while $2 \%$ glutaraldehyde decreased with mean value before $194.20 \pm 206.61$ and after disinfection $2.20 \pm 2.28$. Comparison of the difference in mean number of bacterial colonies between $70 \%$ alcohol group and $2 \%$ glutaraldehyde group did not show a significant difference $(p=$ 0.412).

Conclusion: Based on the results, it can be concluded that there is no significant difference in the number of bacterial colonies between $70 \%$ alcohol and $2 \%$ glutaraldehyde. From the results, it can be concluded that there was nothing better in the act of disinfection of dental chair units using $70 \%$ alcohol and $2 \%$ glutaraldehyde in reducing the number of bacteria.
Department of Oral and Maxillofacial Surgery, Faculty of Dentistry, University of Sumatera Utara, Medan, Indonesia
*Correspondence to: Hendry Rusdy, Department of Oral and Maxillofacial Surgery, Faculty of Dentistry, University of Sumatera Utara, Medan, Indonesia hendry.rusdy@usu.ac.id

Received: 19 September 2018 Revised: 8 January 2020 Accepted: 5 March 2020 Available Online: 1 April 2020

Keywords: Disinfection, Dental chair unit, 70\% alcohol, 2\% glutaraldehyde.

Cite this Article: Rusdy H, Siregar D, Riza A, Siregar IB, Sari NM. 2020. Comparison of 70\% alcohol and $2 \%$ glutaraldehyde effectiveness to the amount of bacterial colonies on the dental chair unit In Department of Oral and Maxillofacial Surgery Faculty of Dentistry University of Sumatera Utara. Journal of Dentomaxillofacial Science 5(1): 39-41. D0I: 10.15562/jdmfs.v5i1.811

\section{Introduction}

Dental health workers are at very high risk of cross-infection with pathogenic microorganisms in the oral cavity and respiratory system such as Human Immunodeficiency Virus (HIV), hepatitis $\mathrm{B}$ and $\mathrm{C}$, mycobacterium tuberculosis, streptococcus, staphylococcus and other bacteria and viruses. The risk of infection can be obtained from contact with blood, saliva, aerosols, or contaminated instruments while performing treatment in patients. Control infection procedures in dental practice include risky infectious disease vaccines such as Hepatitis B, instrument and work environments sterilization, raising universal precautions, applying infection control guidelines and using personal protective equipment such as gloves, masks, protective eyewear and face shields, and using protective clothing while working. ${ }^{1}$

The commonly used cross infection management procedure is based on rules issued by The Centers for Disease Control and Prevention (CDC). ${ }^{3}$ In dental practice, standard precautions include six important parts: patient evaluation, self protection, instrument processing (sterilization), asepsis and surface disinfection, use of disposable equipment and medical waste disposal. ${ }^{2,3}$

Disinfection is to kill pathogenic microorganisms physically or chemically, this can reduce the possibility of infection. ${ }^{3,4}$ There are several disinfectants commonly used in dentistry, including $2 \%$ glutaraldehyde and 70\% alcohol. ${ }^{4}$

A research conducted by Rusmiany. ${ }^{5}$ regarding the immersion of alginate cast material with $2 \%$ glutaraldehyde for 10 minutes, 15 minutes and 25 minutes, it was found that $2 \%$ glutaraldehyde can prevent the contamination of mycrobacterium tuberculosis in cast materials $(\mathrm{p}=0.00) .{ }^{5} \mathrm{~A}$ research conducted by Utami et al. ${ }^{6}$ about the antibacterial strength of an disinfectant agent for a root canal preparation instrument using $5.25 \%$ sodium hypochlorite, $2 \%$ glutaraldehyde and glutaraldehyde-based disinfectant for B. Subtilis. It can be concluded that $2 \%$ glutaraldehyde has the greatest 
antibacterial strength against B. Subtilis, followed by glutaraldehyde-based disinfectants, and the weakest antibacterial strength was $5.25 \%$ sodium hypochlorite. ${ }^{6}$

A research conducted by Pramita et al. ${ }^{7}$ reported that washing with $70 \%$ alcohol caused a decrease in the amount of nosocomial germs attached to the stethoscope membrane $(\mathrm{p}<0.05){ }^{7}{ }^{7}$ The results of the study are parallel which examined the effectiveness of 70\% alcohol as a disinfectant on various germs on the stethoscope membrane, by spraying and submerging the stethoscope membrane for 10 minutes, the result was $70 \%$ alcohol could reduce the amount of bacterial colonies to $91 \%$ of each membrane stethoscope. ${ }^{8}$ Gunawan..${ }^{9}$ reported that $70 \%$ alcohol was able to reduce the amount of staphylococcal bacteria to $100 \%$, where the amount of colonies before disinfection was 15 decreased to $0 .{ }^{9}$

\section{Material and Methods}

This study is an experimental study with pretestposttest design conducted on 10 dental chair units in the Department of Oral and Maxillofacial Surgery at the Faculty of Dentistry, University of Sumatera Utara.

The sample was divided into two groups, in which 5 dental chair units were disinfected using $70 \%$ alcohol and 5 other dental chair units were disinfected using $2 \%$ glutaraldehyde. The samples were taken by swabbing four parts of the dental chair unit; headrests, armrests, dental chairs and spittoon bowl before and after disinfection. After swabbing, the cotton swab was put into a test tube containing $0.9 \% \mathrm{NaCl}$ and then diluted two times. The data was obtained from the calculation of the amount of bacteria in the Agar Plate Count media. The results were statistically analyzed using paired $\mathrm{t}$-test and unpaired t-test.

\section{Results}

From the Shapiro Wilk normality test, the results obtained are $p>0.05$, where the data is normally distributed. The test is used to determine the differences between the pre and post observations. Paired

Tabel 1 The number of bacterial colonies on 10 dental chair unit before and after disinfection with $70 \%$ alcohol and $2 \%$ glutaraldehyde

\begin{tabular}{lccc}
\hline Variabel & $\begin{array}{c}\text { Mean } \pm \text { SD } \\
\text { (Before) }\end{array}$ & $\begin{array}{c}\text { Mean } \pm \text { SD } \\
\text { (After) }\end{array}$ & P-value \\
\hline $70 \%$ alcohol & $318.20 \pm 217.52$ & $11.20 \pm 17.29$ & 0.03 \\
2\% glutaraldehyde & $194.20 \pm 206.61$ & $2.20 \pm 2.28$ & 0.105 \\
\hline
\end{tabular}

Tabel 2 Data analysis using unpaired t-test

\begin{tabular}{lcc}
\hline Groups & Mean \pm SD & P-value \\
\hline $70 \%$ alcohol & $307 \pm 214.81$ & \\
2\% glutaraldehyde & $192 \pm 205.65$ & 0.412 \\
\hline
\end{tabular}

$\mathrm{t}$-test is used to determine the effectiveness of the treatment. Unpaired t-test is then used to compare between the two groups.

Based on the paired t-test results table 1 it was found that the $70 \%$ alcohol group has a mean value of $318.20 \pm 217.52$ number of bacteria before disinfection, while the mean value of bacteria after disinfection is $11.20 \pm 17.29$ with the $p$ value $=0.03<0.05$, it can be concluded that the null hypothesis is rejected or there is a significant difference in the amount of bacteria before and after disinfection using $70 \%$ alcohol. The results of data analysis for the $2 \%$ glutaraldehyde group, it was found that the $2 \%$ glutaraldehyde has a mean value of $194.20 \pm 206.61$ number of bacteria before disinfection, while the mean value of bacteria after disinfection is $2.20 \pm 2.28$ with the $\mathrm{p}$ value $=0.105>0.05$, it can be concluded that the null hypothesis is accepted or there is no significant difference in the number of bacteria before and after disinfection using $2 \%$ glutaraldehyde.

Based on the unpaired t-test results table 2 comparing the results from the two groups, the results obtained was $p$ value $=0.412>0.05$, there is no significant difference in the number of bacterial colonies between the $70 \%$ alcohol and 2\% glutaraldehyde.

\section{Discussion}

Based on the results using $70 \%$ alcohol in 5 dental chair units, obtained $\mathrm{p}$ value $=0.03$, means that there were significant differences in the amount of bacteria before and after disinfection. This result is in accordance with the research conducted by Pramita et al. ${ }^{7}$ they reported that washing with $70 \%$ alcohol caused a decrease in the amount of nosocomial germs attached to the stethoscope membrane, as well as a study conducted by Susatyo. ${ }^{8}$ where the results showed that polishing and soaking using $70 \%$ alcohol in dental equipment could reduce the number of germs, where the mean value of germs before treatment is $79349.4 \mathrm{CFU} / \mathrm{cm} 2$ and the mean value after being smeared and soaked with $70 \%$ alcohol is $13.4 \mathrm{CFU} / \mathrm{cm} 2{ }^{8.9}$ This is because alcohol is a protein regulation, a characteristic which primarily provides antimicrobial activity on alcohol. In addition, alcohol can also dissolve fat in cell membranes and denature biomolecules (DNA, RNA, lipids) that are important for bacterial growth and development. ${ }^{11}$ 
Based on the results, $2 \%$ glutaraldehyde is able to reduce the number of bacterial colonies, but after the statistical tests it was obtained that the $p$ value $=0.105$, which means that statistically $2 \%$ glutaraldehyde was not significant in reducing the number of bacteria. This can happen because the number of sample used in this study is too small to obtain significant results. With a small number of sample, the sampling errors tend to be large and this often causes the test to be insignificant even when the observed differences are caused by real effects. ${ }^{11}$

The comparison of data analysis of $70 \%$ alcohol and 2\% glutaraldehyde using unpaired t-test showed a non-significant comparison where $\mathrm{p}>0.05$ $(\mathrm{p}=0.412)$, it can be concluded that there is no significant difference from the amount of bacterial colonies between $70 \%$ alcohol and $2 \%$ glutaraldehyde. This shows that $70 \%$ alcohol and $2 \%$ glutaraldehyde are equally effective in reducing the number of bacteria on the dental chair unit.

\section{Conclusion}

Based on the results and data analysis, disinfection of dental chair units using $70 \%$ alcohol was effective in reducing the number of bacteria and statistically significant with $\mathrm{p}<0.05(\mathrm{p}=0.03)$, while disinfection using $2 \%$ glutaraldehyde was effective in reduce the number of bacteria, but not statistically significant with $\mathrm{p}>0.05(\mathrm{p}=0.105)$.

The comparison of data analysis of $70 \%$ alcohol and 2\% glutaraldehyde group showed a non-significant comparison where $\mathrm{p}>0.05$ $(\mathrm{p}=0.412)$, it can be concluded that there is no significant difference in the number of bacterial colonies between $70 \%$ alcohol and $2 \%$ glutaraldehyde group. From the results, it can be concluded that there was nothing better in the act of disinfection of dental chair units using $70 \%$ alcohol and $2 \%$ glutaraldehyde in reducing the amount of bacteria.

\section{Acknowledgment}

The authors state no funding to declare.

\section{Conflict of Interest}

The author report no conflict of interest.

\section{References}

1. Samad R, Rawiyah U, Septiany C. The frequency of wearing protective eyewear and face shield at educational hospital and public service Hospital in Makassar. J Dentomaxillofac Sci 2017;2: 124.

2. Yanti GN. The relationship between knowledge, trust, availability of facilities, regulations and supervision in the hospital with the behavior of dentists in applying the precaution standard in Medan City Hospital. Medan: FKM USU; 2013. p. 3-4. (In Indonesia)

3. Barenghi L, Barenghi A, Di-Blasio A. Implementation of recent infection prevention procedures published by centers for disease control and prevention: difficulties and problems in orthodontic offices. Iran J Orthod 2017;13: e10201.

4. Thusu S, Panesar S, Bedi R. Patient safety in dentistry-state of play as revealed by a national database of errors. Br Dent J 2012;213: E3.

5. Oosthuysen J, Potgieter E, Fossey A. Compliance with infection prevention and control in oral health-care facilities: a global perspective. Int Dent J 2014;64: 297-311.

6. Utami SP, Mulyawati E, Soebandi DH. Comparison of disinfecting antibacterial power of instrument preparation of canal sodium hypochlorite $5.25 \%$, glutaraldehyde $2 \%$, and glutaraldehyde-based disinfectant against bacillus subtilis. J Kedok Gigi 2016;7: 155. (In Indonesia)

7. Pramita H, Abduh S, Chodidjah. The difference in effectiveness between $70 \%$ alcohol and $0.5 \%$ chlorine on the amount of germs on the stethoscope membrane. Peer Review/Turnitin J/ Proceeding 2011;3: 67. (In Indonesia)

8. Susatyo JH. Differences in the effect of $70 \%$ alcohol rubbing and soaking on a decrease in the number of germ counts in dental equipment. J Vokasi Kesehatan 2016;2: 161. (In Indonesia)

9. Cleveland JL, Gray SK, Harte JA, et al. Transmission of blood-borne pathogens in US dental health care settings: 2016 update. J Am Dent Assoc 2016;147: 729.

10. Adji D, Zuliyanti, Larashanty H. Perbandingan efektivitas sterilisasi alkohol 70\%, inframerah, otoklaf dan ozon terhadap pertumbuhan bakteri bacillus subtilis. J. Sain Vet 2007;25: 21.

11. Acosta-Gio E, Bednarsh H, Cuny E. Sterilization of dental handpieces. Am J Infect Control 2017;45: 937-938.

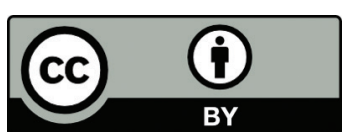

This work is licensed under a Creative Commons Attribution 